\title{
THE EFFECTS OF PROPISCIN ON THE CARDIAC RATE OF ISOLATED HEART OF COMMON CARP, CYPRINUS CARPIO L.
}

\author{
Grzegorz J. HAJEK ${ }^{1 *}$, Bernard KŁYSZEJKO ${ }^{1}$, Robert DZIAMAN ${ }^{1}$ \\ Edyta PACZKOWSKA ${ }^{2}$ \\ ${ }^{1}$ Division of Fish Physiology, Agricultural University of Szczecin, Poland \\ ${ }^{2}$ Division of General Pathology, Pomeranian Medical University, Szczecin, Poland
}

\begin{abstract}
Hajek G.J., Kłyszejko B., Dziaman R., Paczkowska E., 2004. The effects of Propiscin on the cardiac rate of isolated heart of common carp, Cyprinus carpio L. Acta Ichthyol. Piscat. 34 (2): 145-153.
\end{abstract}

Background. The use of anaesthetics in aquaculture requires conducting specific physiological studies of its effect on fish. The objective of this study was to evaluate the direct effect of Propiscin (IRS Olsztyn, Poland) on the rate of isolated heart of common carp. Material and methods. The activity of isolated, perfused heart was recorded using an electrocardiograph. Propiscin was applied at concentrations of 2, 10, and $100 \mathrm{ml} \cdot \mathrm{l}^{-1}$ of perfusion medium.

Results. The study revealed a stimulating effect of Propiscin applied at a concentration of $10 \mathrm{ml} \cdot \mathrm{l}^{-1}$, a depressing effect being recorded at a concentration of $100 \mathrm{ml} \cdot \mathrm{l}^{-1}$. No effects were observed at the Propiscin concentration of $2 \mathrm{ml} \cdot \mathrm{l}^{-1}$.

Conclusion. It has been concluded that bradycardia accompanying the anaesthesia evoked by Propiscin at concentrations of 1 and $2 \mathrm{ml} \cdot \mathrm{l}^{-1}$ of water is not a result of direct effect of Propiscin on the carp's heart.

Key words: fish, anaesthesia, Propiscin, etomidate, isolated heart, common carp.

\section{INTRODUCTION}

Propiscin has been one of the most popular aquaculture anaesthetics in Poland. It contains etomidate and is used to evoke general anaesthesia in fish (Kazun and Siwicki 2001). The depressive effect of this agent on the heart action and ventilation in carp, Cyprinus carpio L., was described by Hajek and Kłyszejko (2004). The recorded bradycardia accompanying the anaesthesia was concluded to be a result of hypoxia. This study concentrates on examination of the direct effect of Propiscin on isolated and perfused carp heart.

* Correspondence: Dr Grzegorz J. Hajek, Zakład Fizjologii Ryb, WNoŻiR, Akademia Rolnicza, ul. Kazimierza Królewicza 4, 71-550 Szczecin, Poland, e-mail: gjh@fish.ar.szczecin.pl 


\section{MATERIALS AND METHODS}

The experiments involved Propiscin, a preparation manufactured at the Division of Fish Pathology and Immunology at Żabieniec (Inland Fisheries Institute in Olsztyn, Poland) and used for short-term general anaesthesia of fish; the preparation's active substance is etomidate $(0.2 \%)$.

The heparinised fish, ranging in size from 190-370 g, were sacrificed by severing the vertebral cord. The heart, dissected out along with the pericardium, was rinsed in the perfusion saline. A 2-mm outer diameter polythene tubing was inserted into the venous sinus. The sinus fragment covering the tubing was tied with a thread and the heart was placed in the observation system (Fig. 1), where it was submerged in a constant volume of the perfusate.

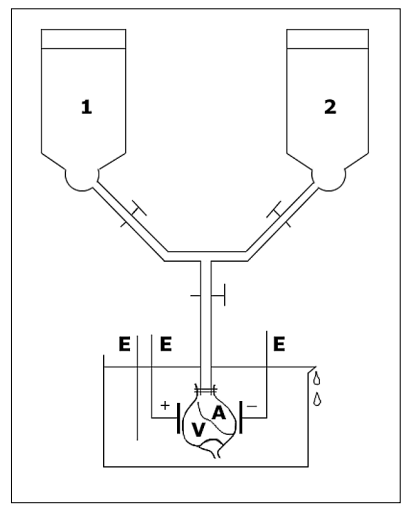

Fig. 1. A diagram of the perfusion apparatus; 1 , reservoir with perfusate; 2 , reservoir with Propiscin solution in perfusion medium; E, electrodes; A, atrium; V, ventricle

The heart was performing regular contractions and pumped the saline-under a constant pressure-from one of the reservoirs. The pumping rate was adjusted to the heart dimensions which was about $6 \mathrm{ml} \cdot \mathrm{min}^{-1}$. Doubling or halving of the flow rate produced no change in the cardiac rate.

The heart activity was recorded with an Askard B5 electrocardiograph with two discoid AgCl-coated silver electrodes. The QRS complex varied from 0.15 to $0.73 \mathrm{mV}$.

The perfusion fluid was kept at a constant temperature of $20 \pm 0.2^{\circ} \mathrm{C}$.

The perfusion medium contained $7.0 \mathrm{~g} \mathrm{NaCl}, 1.5 \mathrm{~g} \mathrm{NaHCO}_{3}, 0.3 \mathrm{~g} \mathrm{KCl}$, and $0.15 \mathrm{~g}$ $\mathrm{CaCl}_{2}$ in 11 .

The study consisted of the following 4 experimental treatments, each involving 7 isolated carp hearts:

I. Recording the activity of a heart pumping the perfusate for 20 minutes.

II. Recording the cardiac activity at a Propiscin concentration of $2 \mathrm{ml} \cdot \mathrm{l}^{-1}$ of perfusate: after 5 minutes under control conditions, the Propiscin was applied for $7 \mathrm{~min}$ and the system was switched back to pure perfusate. 
III. Recording the cardiac activity at a Propiscin concentration of $10 \mathrm{ml} \cdot \mathrm{l}^{-1}$ of perfusate; 7 min exposure.

IV. Recording the cardiac activity at a Propiscin concentration of $100 \mathrm{ml} \cdot \mathrm{l}^{-1}$ of perfusate; 7 min exposure.

The data obtained were subjected to statistical treatment. The Wilcoxon paired test was applied to test for significance of differences between cardiac rate frequencies at various times of Propiscin exposure and the initial, control frequencies. Results were considered significant if $P<0.05$.

\section{RESULTS}

The rate of a heart pumping a pure perfusion fluid was very stable, with a slight but insignificant tendency to decrease (Fig. 2).

Initially, the average heart rate was 67.57 , which decreased to 60.14 after $20 \mathrm{~min}$. In addition, a gradual reduction in the QRS complex amplitude by about 30 percentage points over $20 \mathrm{~min}$ was observed.

The heartbeat frequency recorded this way was used (along with control values registered at the onset of each Propiscin run) as a reference against which to evaluate changes produced by exposure to the anaesthetic.

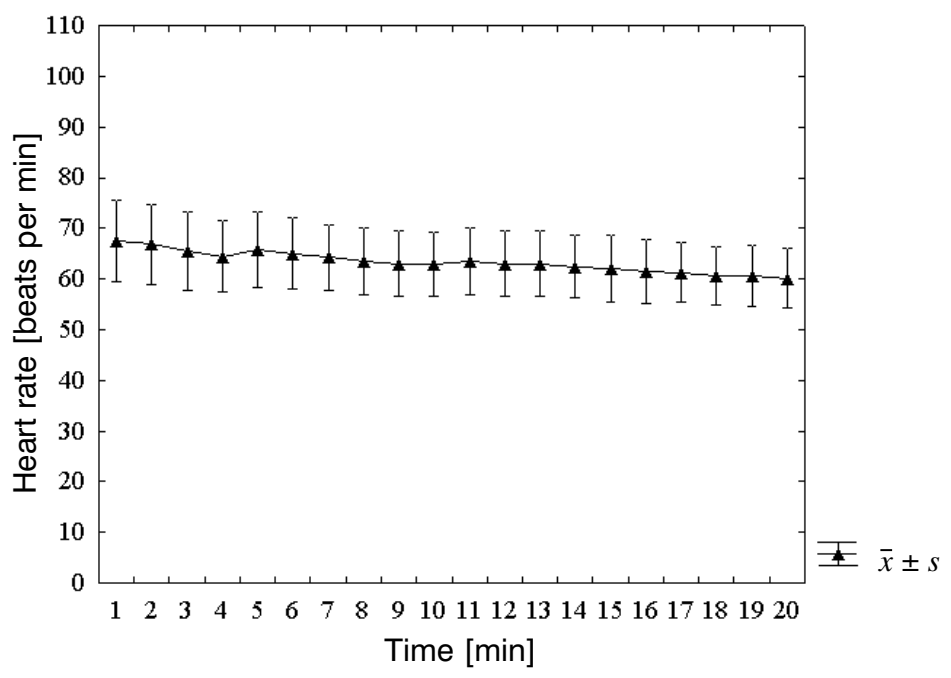

Fig. 2. Rate of isolated, perfused carp heart

The effect of Propiscin applied at a concentration of $2 \mathrm{ml} \cdot \mathrm{l}^{-1}$ of perfusion medium on isolated carp heart rate is presented in Fig. 3.

There were no statistically significant changes in the rate during the exposition (Table 1). 


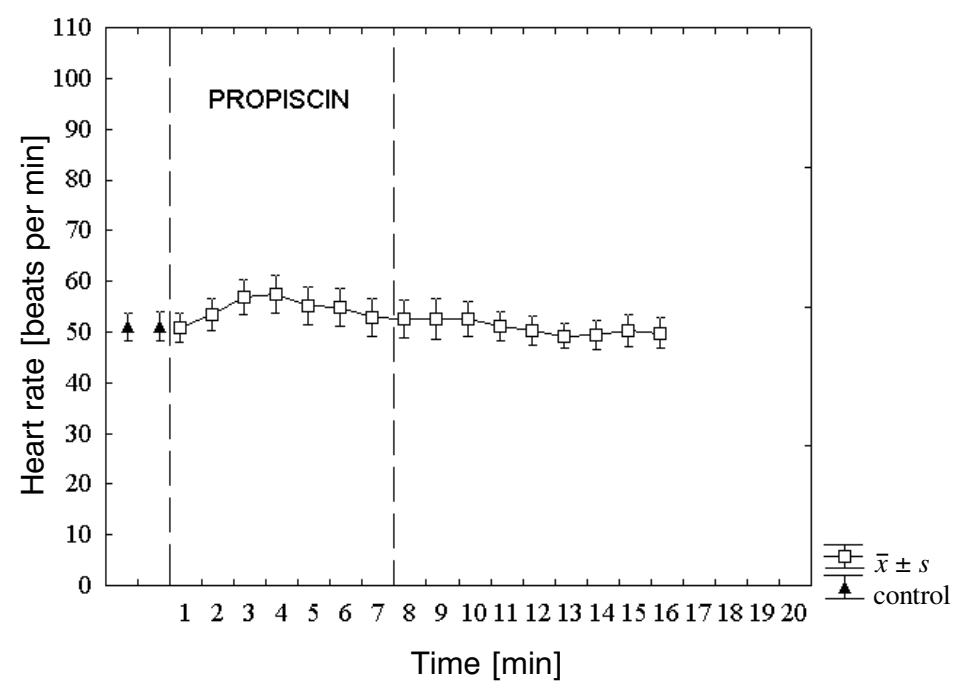

Fig. 3. The effect of Propiscin at a concentration of $2 \mathrm{ml} \cdot \mathrm{l}^{-1}$ on the rate of isolated, perfused carp heart

Table 1

Comparison of heart rates of isolated perfused carp heart under control conditions with rates effected by the exposure to Propiscin concentration of $2 \mathrm{ml} \cdot \mathrm{l}^{-1}$ of perfusion medium

\begin{tabular}{cccc}
\hline $\begin{array}{c}\text { Control vs. Propiscin treatment } \\
\text { in sequential minutes }\end{array}$ & $\begin{array}{c}\text { Group } \\
\text { size }\end{array}$ & $\begin{array}{c}t \text { statistic of Wilcoxon } \\
\text { paired test }\end{array}$ & $\begin{array}{c}\text { Significance } \\
\text { level } P\end{array}$ \\
\hline 1 & 7 & 9 & 0.75 \\
2 & 7 & 8 & 0.60 \\
3 & 7 & 3.5 & 0.07 \\
4 & 7 & 3 & 0.11 \\
5 & 7 & 9 & 0.39 \\
6 & 7 & 10 & 0.49 \\
7 & 7 & 13 & 0.86 \\
8 & 7 & 13 & 0.86 \\
9 & 7 & 13 & 0.86 \\
10 & 7 & 10 & 0.91 \\
11 & 7 & 12 & 0.73 \\
12 & 7 & 10.5 & 0.55 \\
13 & 7 & 5 & 0.24 \\
14 & 7 & 9.5 & 0.44 \\
15 & 7 & 13 & 0.86 \\
16 & 7 & 7.5 & 0.52 \\
\hline
\end{tabular}


The effect of Propiscin applied at a concentration of $10 \mathrm{ml} \cdot \mathrm{l}^{-1}$ of perfusate on the isolated carp heart rate is presented in Fig. 4.

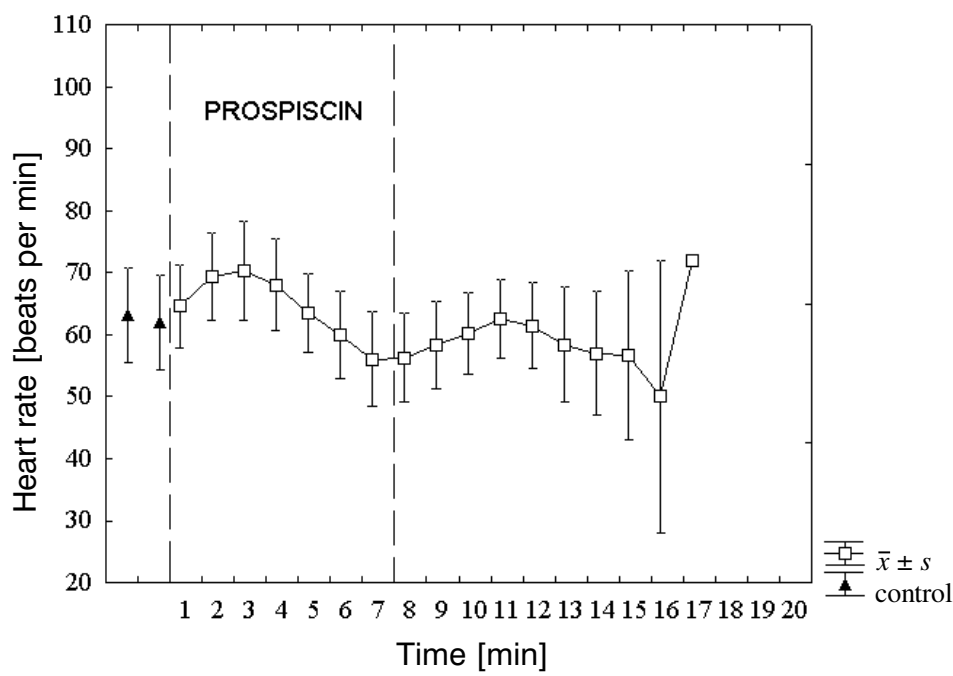

Fig. 4. The effect of Propiscin at a concentration of $10 \mathrm{ml} \cdot \mathrm{l}^{-1}$ on the rate of isolated, perfused carp heart

Propiscin caused a clear acceleration of the heartbeat. In the 2nd min of the exposure, the heart rate was significantly different from the control (Table 2).

As the Propiscin flow was terminated, the cardiac rhythm reverted to the initial state. During the final minutes of the run, the rates recorded in individual samples showed a wide scatter.

The effect of Propiscin applied at a concentration of $100 \mathrm{ml} \cdot \mathrm{l}^{-1}$ of perfusate on isolated carp heart rate is presented in Fig. 5.

At $3 \mathrm{~min}$ of the run, the heart rate was accelerated, although-due to a wide scatter of the initial values - the change did not cross the significance threshold (Table 3).

Subsequently, a strong reduction in pumping frequency to a mean of 10.2 in 7 th min of exposure was recorded. In some cases, the heartbeat ceased altogether, but the effect was reversible. Substitution of pure perfusate for the Propiscin solution resulted in acceleration of the heart rate and the rhythm reverted to a level close to the initial, control one. 
Table 2

Comparison of heart rates of isolated perfused carp heart under control conditions with rates effected by the exposure to Propiscin concentration of $10 \mathrm{ml} \cdot \mathrm{l}^{-1}$ of perfusion medium; statistically significant differences are marked with bold type

\begin{tabular}{cccc}
\hline $\begin{array}{c}\text { Control vs. Propiscin treatment } \\
\text { in sequential minutes }\end{array}$ & $\begin{array}{c}\text { Group } \\
\text { size }\end{array}$ & $\begin{array}{c}t \text { statistic of Wilcoxon } \\
\text { paired test }\end{array}$ & $\begin{array}{c}\text { Significance } \\
\text { level } P\end{array}$ \\
\hline 1 & 7 & 3.5 & 0.14 \\
$\mathbf{2}$ & 7 & $\mathbf{0}$ & $\mathbf{0 . 0 1}$ \\
3 & 7 & 2.5 & 0.05 \\
4 & 7 & 7 & 0.23 \\
5 & 7 & 11 & 0.61 \\
6 & 7 & 14 & 1 \\
7 & 7 & 9.5 & 0.44 \\
8 & 7 & 12 & 0.73 \\
9 & 7 & 11 & 0.61 \\
10 & 7 & 13 & 0.86 \\
11 & 7 & 10 & 0.91 \\
12 & 7 & 12.5 & 0.79 \\
13 & 5 & 7.5 & 1 \\
14 & 5 & 6.5 & 0.78 \\
15 & 3 & 1.5 & 0.42 \\
16 & 2 & 0 & \\
\hline
\end{tabular}

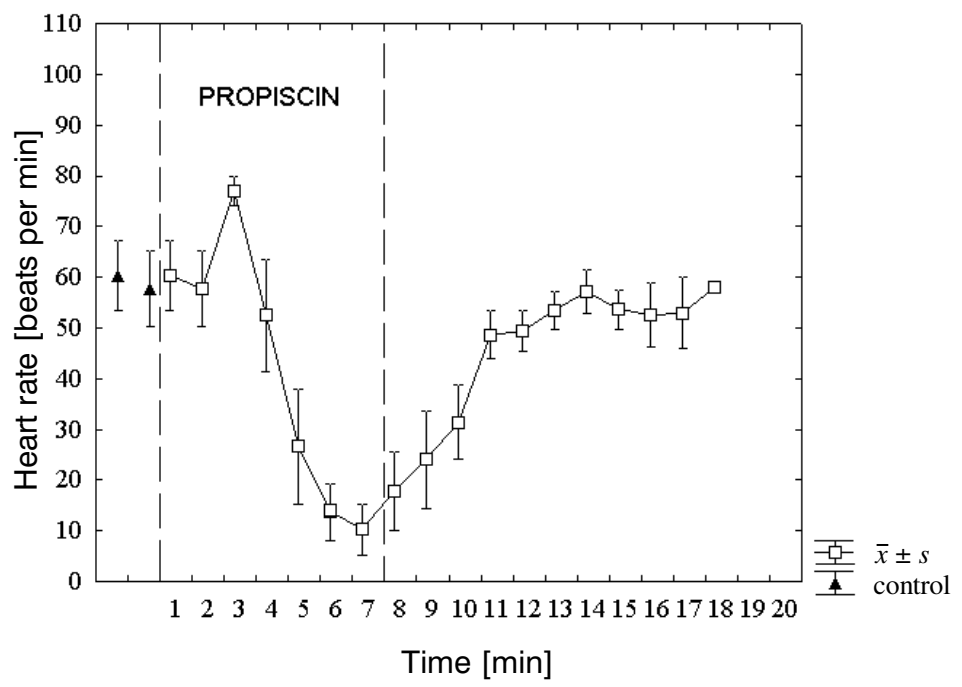

Fig. 5. The effect of Propiscin at a concentration of $100 \mathrm{ml} \cdot \mathrm{l}^{-1}$ on the rate of isolated, perfused carp heart 
Table 3

Comparison of heart rates of isolated perfused carp heart under control conditions with rates effected by the exposure to Propiscin concentration of $100 \mathrm{ml} \cdot \mathrm{l}^{-1}$ of perfusion medium; statistically significant differences are marked with bold type

\begin{tabular}{cccc}
\hline $\begin{array}{c}\text { Control vs. Propiscin treatment in } \\
\text { sequential minutes }\end{array}$ & $\begin{array}{c}\text { Group } \\
\text { size }\end{array}$ & $\begin{array}{c}t \text { statistic of Wilcoxon } \\
\text { paired test }\end{array}$ & $\begin{array}{c}\text { Significance } \\
\text { level } P\end{array}$ \\
\hline 1 & 7 & 3 & 0.06 \\
2 & 7 & 11.5 & 0.67 \\
3 & 7 & 4 & 0.09 \\
$\mathbf{4}$ & 7 & $\mathbf{0}$ & $\mathbf{0 . 0 1}$ \\
$\mathbf{5}$ & 7 & $\mathbf{0}$ & $\mathbf{0 . 0 1}$ \\
$\mathbf{6}$ & 7 & $\mathbf{1}$ & $\mathbf{0 . 0 2}$ \\
$\mathbf{7}$ & 7 & $\mathbf{1}$ & $\mathbf{0 . 0 2}$ \\
$\mathbf{8}$ & 7 & $\mathbf{1}$ & $\mathbf{0 . 0 2}$ \\
9 & 7 & 3 & 0.11 \\
10 & 7 & 6 & 0.17 \\
11 & 7 & 6 & 0.17 \\
12 & 7 & 12.5 & 0.79 \\
13 & 5 & 3 & 0.46 \\
14 & 3 & 3 & 1 \\
\hline
\end{tabular}

\section{DISCUSSION}

Propiscin at the concentration of $2 \mathrm{ml} \cdot \mathrm{l}^{-1}$ did not effect the rate of isolated, perfused carp heart. Results of our previous study (Hajek and Kłyszejko 2004) demonstrated that Propiscin at the concentrations of 1 and $2 \mathrm{ml} \cdot \mathrm{l}^{-1}$ evoked bradycardia in anaesthetized carp. It can be concluded that reduction in heart rate accompanying the anaesthesia evoked by Propiscin is not a result of direct effect of this agent on the carp's heart.

At every Propiscin concentration applied in this study, the first response of the heart to the presence of the anaesthetics in the perfusion fluid was an increase in heart rate but the changes were statistically significant only at Propiscin concentration of $10 \mathrm{ml} \cdot \mathrm{l}^{-1}$.

Very few data on stimulating effect of etomidate could be found in the published literature. It is only Riou et al. (1990) who found a weak, positive inotropic effect of etomidate at concentrations of 1 and $5 \mu \mathrm{g} \mathrm{ml}^{-1}$ on stimulated fragments of rat cardiac muscle.

The present study demonstrated that Propiscin at a concentration of $100 \mathrm{ml} \cdot \mathrm{l}^{-1}$ of perfusate induced, after a short period of acceleration, a strong reduction in the heart rate. Once the exposure was terminated, the heart rate reverted to its initial frequency. This concentration is extreme, many times greater than that used in practice. However, the changes it produced were reversible. 
The chronotropically and inotropically negative effect of etomidate applied at clinical concentrations $\left(0.15-0.30 \mathrm{mg} \cdot \mathrm{kg}^{-1}\right)$ and greater than those used routinely has been frequently found. Stowe et al. (1992) recorded a reduction in heart rate during exposure of an isolated perfused guinea pig heart to etomidate. The negatively inotropic effect in the rat heart was reported by Suzer et al. (1998). The depressing effect on contractility of stimulated fragment of the human heart muscle was reported by Gelissen et al. (1996) and by Sprung et al. (2000). The effect depended on the concentration of the anaesthetic. Clinical concentrations induced no depressing effect. A similar result was obtained by testing an isolated fragment of canine (Kissin et al. 1983) and polecat (Mattheussen and Housmans 1993) ventricle. The contractility changes could have been related to disturbed flow of calcium ions in the heart muscle cells (Mattheussen and Housmans 1993, Takahashi and Terrar 1994, Buljubasic et al. 1996).

\section{CONCLUSIONS}

The study revealed a stimulating effect of Propiscin applied at the $10 \mathrm{ml} \cdot \mathrm{l}^{-1}$ concentration, a depressing effect being recorded at a concentration of $100 \mathrm{ml} \cdot \mathrm{l}^{-1}$. No statistically significant effects were observed at the Propiscin concentration of $2 \mathrm{ml} \cdot \mathrm{l}^{-1}$. It has been concluded that Propiscin at concentrations used in aquaculture practice has no direct effect on the heart of anaesthetized carp.

\section{REFERENCES}

Buljubasic N., Marijic J., Berczi V., Supan D.F., Kampine J.P., Bosnjak Z.J., 1996. Differential effects of etomidate, propofol, and midazolam on calcium and potassium channel currents in canine myocardial cells. Anesthesiology 85: 1092-1099.

Gelissen H.P., Epema A.H., Henning R.H., Krijnen H.J., Hennis P.J., den Hertog A., 1996. Inotropic effects of propofol, thiopental, midazolam, etomidate and ketamine on isolated human atrial muscle. Anesthesiology 84 (2) : 397-403.

Hajek G., Kłyszejko B., 2004. The effects of Propiscin (etomidate) on the behaviour, heart rate, and ventilation of common carp, Cyprinus carpio L. Acta Ichthyologica et Piscatoria 34 (2): 129-143.

Kazuń K., Siwicki A.K., 2001: Propiscin—a safe new anaesthetic for fish. Archives of Polish Fisheries 9 (2): 183-190.

Kissin I., Motomura S., Aultman D.F., Reves J.G., 1983. Inotropic and anesthetic potencies of etomidate and thiopental in dogs. Anesthesia and Analgesia 62 (11): 961-965.

Mattheussen M, Housmans P.R, 1993. Mechanism of the direct, negative inotropic effect of etomidate in isolated ferret ventricular myocardium. Anesthesiology 79 (6): 1284-1295.

Riou B., Lecarpentier Y., Chemla D., Viars P., 1990. In vitro effects of etomidate on intrinsic myocardial contractility in the rat. Anesthesiology 72 (2): 330-340.

Sprung J., Ogletree-Hughes M. L., Moravec Ch.S., 2000. The effects of etomidate on the contractility of failing and nonfailing human heart muscle. Anesthesia and Analgesia 91: $68-75$. 
Stowe D.F., Bosnjak Z.J., Kampine J.P., 1992. Comparison of etomidate, ketamine, midazolam, propofol, and thiopental on function and metabolism of isolated hearts. Anesthesia and Analgesia 74 (4): 547-558.

Suzer O., Suzer A., Aykac Z., Ozuner Z., 1998. Direct cardiac effects in isolated perfused rat hearts measured at increasing concentrations of morphine, alfentanil, fentanyl, ketamine, etomidate, thiopentone, midazolam and propofol. European Journal of Anaesthesiology 15 (4): 480-485.

Takahashi H., Terrar D.A., 1994. Effects of etomidate on whole-cell and single L-type calcium channel currents in guineapig isolated ventricular myocytes. British Journal of Anaesthesia 73 (6): 812-819.

Received: 27 February 2004 Accepted: 13 December 2004 